nation must always be included the buildings they have raised, and the duration of these will depend on the material chosen for the erection. Is it a necessity of modern civilisation that our great edifices should be constructed of materials that are quick to perish? and why should it be said of Anglo-Indian architecture, that if the English left India, in a century after their departure no sign of their occupation would remain? and in India, as Prof. Ball remarks, unlike new countries such as Australia and most parts of America, where knowledge had to be obtained by experience, the native temples and buildings should have at once furnished the needed information as to the durability of the material used in them, the only one quality in building material that nothing save time is a test for. Most of the buildings erected by the British in India are built of brick ; it need scarcely be added that all the native temples are of stone, and that many exhibit a wonderful mastery over sometimes difficult material. Very strange is it, too, to learn that the resources of India in this respect are so little known or appreciated, that at this day advertisements daily meet the eye in the Indian papers of Aberdeen granites and Italian marbles; and yet how many temples are there to be found in India, constructed of native granites? and what can surpass the white marble filigree screens called jalee, made out of the native marble?

One splendid screen is thus described by Mr. Keene : "But all the marble work of Northern India is surpassed by the monument which Akbar erected over the remains of his friend and spiritual counsellor, Shekh Sulim Chisti, at Fatipur Sikri (I581 A.D.). In the north-western angle of a vast courtyard, 433 feet by 366 feet, is a pavilion externally of white marble, surrounded by a deep, projecting dripstone, also of white marble, supported by marble shafts, crowned by most fantastic brackets, shaped like the letter S. The outer screens are so minutely pierced, that at a little distance they look like lace, and illuminate the mortuary chapel within with a solemn halflight which resembles nothing else that I have seen."

The varieties of metamorphic rocks suited to building purposes in India are very numerous; besides the granites, sandstones and porphyritic gneiss abound. In Mysore, a building-stone occurs in the crystalline rock of the district, which can be split into posts twenty feet long, which have been used for the support of the telegraph wires; and the peculiar adaptability of gneiss to fine carving is often to be seen in the rings appended to the drooping corners of some of the pagodas, where the rings, the links within which are movable, and the projecting corners, are carved out of a single block. Among all thc formations, the Great Vindhyan sandstones stand prominent ; these were used in the manufacture of stone implements; the great memorial monoliths or lats, many of which bear the edicts of Asoka, the protector of the early Buddhists who reigned about 250 B.C., are made of this stone; some of these are of great size, and on the exposed surfaces are polished; their carved capitals were surmounted with figures of lions or elephants.

There are many quarries of stone throughout India, opened in these Vindhyan rocks. At Dehri, on Son, the stone is a compact white sandstone, strong and durable, and susceptible of artistic treatment. Other fine quarries are at Chunar, from which has come for ages the supply to Benares and Calcutta. But perhaps the most important quarries in India are those in the Upper Bhanrers, whieh have furnished building material since before the Christian era, to the cities of the adjoining plains. Portions of the Taj at Agra, Akbar's Palace at Fatipur Sikri, the Jamma Masjid at Delhi, have been built from the stone of these quarries. The palace of the Rajah of Bhartpur, at Deeg, one of the most beautiful edifices in India, is constructed of the stone from the same district. In it, cupolas rest on slender shafts of two or three inches in diameter. Arches are supported on strong, yet graceful pillars, and windows are formed of single slabs of stone, perforated with the most elaborate tracery.

Among the sandstones of the Damuda series, there are several varieties which are suited for building purposes. Throughout the Damuda valley, where these rocks occur, they have been used from considerable antiquity for the construction of temples. Among the finest examples known, some Jain temples at Barakar may be mentioned, as they exhibit specimens of wonderful carving which has stood well, though the old Pâli inscriptions on stone of this material in the caves of Sirguja an 1 Chang Bakhar even better testify to the endurance of this rock.

Laterite has also been used as a building material, but it is not ornamental, and does not weather well. Good roofing slate does not appear to exist in India, though in the transition rocks of the Kharakpur Hills, slate occurs ; it is a partially altered earthy rock, which is readily fissile, and with pains and care can be reduced to a thickness of one-eighth of an inch; it would answer well for flagging.

Extended though this notice of Prof. Ball's book has been, we have been unable therein to glance at more than its more prominent features. We doubt not, however, that the reader will perceive that it is one of the most important contributions yet made to our knowledge of the economic geology of this vast kingdom, the prosperity of which so nearly and so intimately concerns ourselves.

\section{THE SCIENCE AND ART DEPARTMENT} \section{$\mathrm{W}^{\mathrm{E}}$ have received the following communication from}

There are few Blue Books that better repay careful study than the admirable reports of the Science and Art Department. The Twenty-eighth Report has recently been issued, and is of exceptional interest. Its bulky appendices contain, as usual, a mass of valuable statistics relating to the diffusion of scientific and artistic instruction among the masses; and in the body of the report we find indications of a general scheme of reorganization, both in the details and the scope of the higher scientific education given in the Science Schools at South Kensington. This scheme has now taken definite shape, and came into operation with the session which has recently opened. It is therefore a fitting opportunity briefly to review the work done by the Science and Art Department in the scientific instruction of the people, and then examine the nature and object of the changes that are being made at South Kensington.

The Great Exhibition of 185 I revealed the fact, that in order to compete with the industries of foreign nations, it was imperative to have artistic and scientific instruction more widely diffused among the middle and lower classes of this country. To accomplish this the Science and Art Department was formed, and to the soundness of the principles laid down by the Prince Consort and the genius and labour of Sir Henry Cole the success of this Department is largely due. This success is not merely to be found in the large numbers attending the classes in connection with the Department; it is to be seen in the growth of artistic and scientific knowledge among the people, and the application of that krowledge to industrial pursuits. A striking testimony of the change, mainly wrought by the Department, is to be found in the report of the French jurors in the last general Exhibition at Paris. This report states :

"English industry in particular, which, from an artistic point of view, seemed greatly in arrear at the Exhibition of $185 \mathrm{I}$, has during the last ten years made amazing progress; and should it continue to advance at the same rate we might soon be left behind. This state of things 
appears to us to merit the most serious attention of the French Government and manufacturers."

The Department had nevertheless to encounter a bitter and unscrupulous opposition in various quarters, and being less anxious to answer its detractors than to do the work intrusted to it, sneers about South Kensington became easy, and a clap-trap denunciation of the Brompton clique went the round of society, and is even now to be found among its dregs. Though for many years the object of persistent and venomous attacks, Sir $H$. Cole, never swerved from the great work committed to his care, and England is now beginning to recognise the debt of gratitude she owes to this truly remarkable man.

And now let us look at the method of encouraging elementary scientific instruction adopted by the Department, and at some of the results of its methods.

The system of certificated science and art teachers was introduced, with payments to both teachers and pupils dependent on the results of an annual examination in May. By this means pupils were attracted from the artizan class, and teachers were glad to have pupils at almost a nominal fee. Through evening instruction alone a moderate income could thus be made by any active and painstaking teacher who complied with the rules laid down by the Department. In this way, irrespective of fees, the teachers of the Science School at Keighley received last year in payments on results nearly $350 l$.; the teachers at the Bristol Trade and Mining School, in the same way, made upwards of 450l.; the teachers at St. Thomas, Charterhouse, nearly $600 l$. ; and the teachers at some of the Science classes in Liverpool nearly 70ol. Similar results are to be found among the certificated art teachers. It is nct surprising that the number of schools in connection with the Department rapidly and steadily increased, till in 1870 there was only one short of 800 science schools, with the large number of 34,283 students under instruction, chiefly during the evenings of the week. Ten years later, in 1880 , these numbers had increased nearly 60 per cent., there being now I39I elementary science schools under the Science and Art Department, with $60,87 \mathrm{I}$ individuals under instruction: 34,678 of these students entered for the annual examination in May, several taking two or more subjects, so that there were over 69,000 papers worked; of these upwards of 45,000 were passed, or more than 65 per cent.; and 12,000 gained a first-class, or say 27 per cent. of the successful papers. Every successful paper entitles the candidate, if in the furst division, to a prize, and the certificated teacher to a money payment.

As might be expected, the inhabitants of the manufacturing districts avail themselves most largely of the May examinations; and it is instructive to note the relative number of individuals receiving elementary science instruction in the different sections of the United Kingdom. Last year there were in England 42,7 I I students, who paid in fees $8963 l$, or a little over $4 s$. each ; and gained 728I prizes and medals, or about one prize to every six students. In Wales there were I 344 students, who paid in fees 1467 ., or a little over $2 s$. each, and gained 184 prizes and medals, or one prize to every seven students.

In Scotland there were 7376 students, who paid in fees $2088 \mathrm{l}$, or $5 s .9 d$. each, and gained 1423 prizes or medals, or one to every five students; in Ireland there were 5369 students, who paid $665 \mathrm{l}$. in fees, or $2 s .5 d$. each, and gained 1267 prizes and medals, or one to every four students. The payment on results to the teachers amounted to 29,900l. for England and Wales, or say 14 s. per pupil, to $5250 l$. for Scotland, or 14s. $2 d$. per pupil, and to 5079 for Ireland, or I8s. 9d. per pupil. The foregoing analysis which we have made of the figures in this report shows that Ireland has the highest proportion of prizewinners, indicating a higher grade of ability on the part of both teachers and pupils; at the same time its students are poorest, or at any rate least inclined to pay for instruction. The smallness of the fees received by the teachers doubtless also acts as a stimulus to the teacher, for it makes his payment almost wholly dependent on the successes of his pupils.

The report unfortunately does not supply any data as to the relative number of boys and girls among the students, an omission that we hope may be supplied in some future reports; for the Department had the honour of recognising the claims of women to educational prizes and distinctions long before any University opened its door to women.

The nature of the subjects selected by the students differs considerably. The following table, which we have summarised from the report, shows a singular and suggestive difference in national traits; the figures indicate the number of individuals under instruction in 1880 :-

\begin{tabular}{|c|c|c|c|c|c|}
\hline & $\begin{array}{l}\text { Geome- } \\
\text { trical } \\
\text { drawing. }\end{array}$ & $\begin{array}{l}\text { Mathe- } \\
\text { matics. }\end{array}$ & $\begin{array}{c}\text { Me- } \\
\text { chanics. }\end{array}$ & Physics. & $\begin{array}{l}\text { Che- } \\
\text { mistry. }\end{array}$ \\
\hline 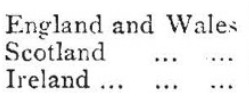 & $\begin{array}{r}17,494 \\
2,229 \\
292\end{array}$ & $\begin{array}{r}1 \mathrm{I}, 08 \mathrm{I} \\
3,050 \\
2,738\end{array}$ & $\begin{array}{r}4,293 \\
1,226 \\
982\end{array}$ & $\begin{array}{r}15,401 \\
1,477 \\
3,212\end{array}$ & $\begin{array}{r}7,732 \\
1,475 \\
439\end{array}$ \\
\hline & Geology. & Biclogy. & Steam. & $\begin{array}{l}\text { Physio- } \\
\text { graphy. }\end{array}$ & $\begin{array}{l}\text { Agri- } \\
\text { culture. }\end{array}$ \\
\hline 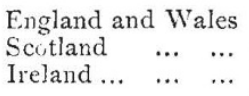 & $\begin{array}{r}2,092 \\
416 \\
406\end{array}$ & $\begin{array}{r}9,336 \\
935 \\
821\end{array}$ & $\begin{array}{r}\mathrm{I}, 539 \\
539 \\
105\end{array}$ & $\begin{array}{r}4,435 \\
709 \\
\mathbf{I}, 521\end{array}$ & $\begin{array}{r}2,772 \\
548 \\
3,104\end{array}$ \\
\hline
\end{tabular}

It will be seen from this that in England the majority select geometrical drawing, next to that physics, and then mathematics. In Scotland the majority choose mathematics, and next to that geometrical drawing; very few selecting agriculture. In Ireland the majority select physics, and almost as many agriculture; next to that being mathematics, and very few geometrical drawing.

In connection with these statistics we notice that Ireland stands far below England and Scotland in point of the number of its art schools and art students; and this notwithstanding that the Irish are essentially an artistic race, the fame of many Irish artists being well known. In fact, though the number of art students in Ireland is small, the quality of their work is more than twice as good as English or Scotch art students; that is, judged by payments on results, the payment to pupils in English art schools under the Department average in the annual competition about $2 s .3 d$. a head, in the Scotch $2 s .4 d$., in the Irish $5 \mathrm{~s}$. In round numbers, there are in England about 5000 art schools, with some 650,000 pupils; in Scotland there are more than 500 art schools, with some 75.000 pupils; whilst in Ireland there are only 50 to 60 art schools, with 6000 to 7000 pupils. In fact few things are more needed in Ireland than the encouragement of artteaching by local art, by museums, and otherwise; and now that the difficulties and interminable correspondence between the Royal Dublin Society and the Department are at an end, we have no doubt that the able and energetic director of the national collection in Ireland will make this question an object of care.

If we now turn to examine the percentage of failures in the different subjects taught by certificated scienceteachers, we find some surprising results. Not only is there a wide difference in the number of failures in the different subjects, but in the same subject the percentage varies extravagantly in different years. We cannot think this is wholly, or even chiefly, due to the candidates, the variations seem far more likely to be due to differences in stringency on the part of the examiners. Uniformity is 
of course impossible, but a greater unity of action on the part of the Board of Examiners seems necessary. Take, for example, geometrical drawing : there were 39 per cent. of failures in the elementary stage in 1879 , and 50 per cent. in 1880. In botany there were 43 per cent. of failures in 1879 , and 20 per cent. in 1880 . In biology there were upwards of 40 per cent. of failures in 1879 , and only 17 per cent. in I $\delta 80$. In sound, light, and heat $5 \mathrm{I}$ per cent. of failures in 1879, and 35 per cent. in 1880 . Magnetism and electricity on the other hand, is extremely uniform, having 29 per cent. of failures one year and 30 per cent. the next. But if we look at the advanced stage for 1879 the failures vary from 25 per cent. in magnetism and electricity to 60 per cent. in botany, and 82 per cent in biology. These fluctuations, if due to idiosyncrasies on the part of the examiners, are very serious for the teachers who are dependent for their livelihood on the payment by results. The natural result is the teacher selects that subject wherein he thinks there is least chance of failure, and thus we find the number of papers worked in the different subjects follows very closely the ease with which a candidate is likely to pass.

Then, as to the methol of examination. Would it not be possible to introduce a practical examination in physics as well as chemistry? The ad titional expense might in part be met by imposing a small fee for examination, and only those students should be eligible for the practical examination who have passed in the "advanced" stage. A certificate for practical knowledge in special branches of science would be most valuable to its holders, and no teacher should be allowed to obtain payment on results until he has one of these certificates. At present any one with very elementary knowledge indeed can set up as a teacher, and the value of the title "Certificated Teacher under the Science and Art Department" is not what it should be. Moreover, a preliminary examination in writing and spelling, and perhaps elementary drawing, ought, we think, to be passed by every certificated teacher. Again and again has the present writer had the most atrocious spelling and writing, to say nothing of English grammar, come under his notice in the May Examination Papers; and yet if the student answered the questions before bim he was bound to obtain a certificate, and would doubtiess be a full-blown certificated teacher, with a class of pupils, before the year was out.

To meet the need of practical teaching, the Department has lately taken a most admirable step in advance. An arrangement has been made whereby a certain number of carefully-selected teachers have the opportunity of coming to London during the summer vacations, and spending a month to six weeks in the practical study of certain branches of science under the direct personal guidance of the eminent professors at the South Kensington Science Schools. In this way, year by year, from twenty to fifty teachers avail themselves of invaluable instruction in chemistry, physics, mechanics, geology, botany, and agriculture. A number of teachers (some 65 out of 200 applicants) are admitted free to the regular courses of instruction at South Kensington. Furthermore to meet, what to many certificated teachers would be the prohibitive expense of coming to London from the provinces, Government pay their railway fare to and fro, and give them an allowance for board whilst under instruction at South Kensington.

And just in passing we may perhaps ask how it is the Treasury have sanctioned the expense of paying the yearly contingent of Irish teachers going the long distance to and from London, when in Dublin there is a School of Science under the Department equipped with an even larger staff than at South Kensington, and furnished with quite as extensive and as admirable educational appliances? This is just one of those points which are calculated to wound the susceptibilities of Irishmen and to foster the cry for local self-government. Moreover, the claims of the College of Science to take part in the training of assisted teachers become still more evident when we find that there are in England thirty-three training colleges receiving grants from the Department, whilst in Ireland there is not one. We feel, however, that attention has only to be called to this point to lead to some change, if there are no insuperable obstacles in the way.

To return - the need for, and the success of, the scheme for training teachers has led to an important alteration in the scope of the Science Schools at South Kensington. This session it begins its work under the title of the "Normal School of Science," added to that of the Royal School of Mines. As before, Diplomas of Associate are given to those students who successfully pass through the prescribed curriculum, but considerable changes have been made in the curriculum. A student can now gain the title of Associate of the Normal School of Science if he passes successfully in one or more of the following divisions:-(a) Mechanics, (b) Physics, (c) Chemistry, $(d)$ Biology, $(e)$ Geology, $(f)$ Agriculture, and he can gain the Associateship of the Royal School of Mines in $(g)$ Metallurgy and $(h)$ Mining. The course of instruction is the same for all divisions during the first two years, after which it is specialised in accordance with a carefully-prepared scheme. At least a three-years' course is therefore necessary for all candidates for Associateship, the fees amnunting for the first two years to $75 l$, and for the remainder of the time vary from $30 l$. to 4ol. There are, however, several scholarships and free studentships open yearly to competition.

And now we must close this lengthy review. To those who have followed the work alreaty done by the Department of Science and Art, and even to those who, ignorant of it, have troubled themselves to read this article, it must be evident that the anonymous croakers at South Kensington are merely enjoying the English privilege of grumbling, and are doubtless secretly proud of this important Government Department.

\section{AN ELECTRIC BAROMETER}

NOTICING an account of a new electric barometer, brought before the Royal Scottish Society of Arts, which requires some fifty communicating wires, and reads but to the one-tenth of an inch, I venture to senis the following. It aims at solving the problem -that of read-

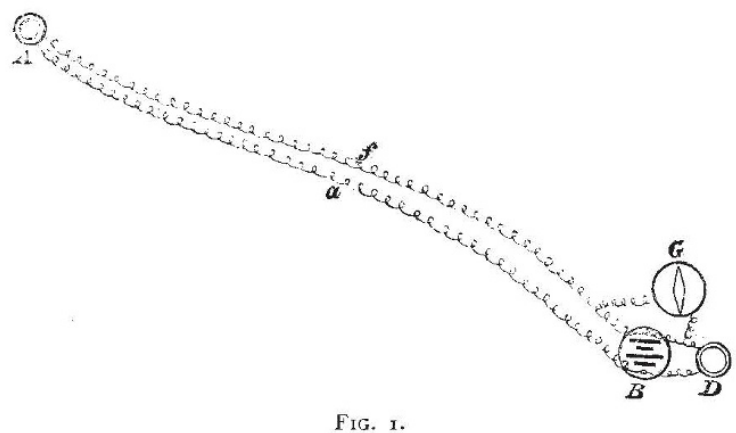

ing a barometer, placed at a distance from an observatory -in a more simple manner.

The barometer, the height of which is to be ascertained, has two platinum wires fused through the glass, at the vacuum end of the tube. One of these is continued by a stout iron wire, the other by a fine carbon thread, both of which are joined at a point in the tube below the level of lowest fall. The iron wire keeps the carbon filament vertical and central in the tube. From the platinum ends outside, wires communicate with the observatory; and a current passed through them, traverses both iron and carbon in its passage. 